\title{
Evaluation of Geotourism Potential of Eruku and Its Environs: A Case for llado Hill
}

\section{Olufemi S. BAMIGBOYE ${ }^{1 *}$, Toba E. BAMIDELE ${ }^{1}$, Shakirat O. MUSTAPHA ${ }^{1}$, Olufemi OLANIYAN ${ }^{1}$ and Moses O. AWOJOBI ${ }^{1}$}

\author{
${ }^{1}$ Geology and Mineral Sciences Department, Kwara State University, Malete, Nigeria \\ *Corresponding Author: olufemi.bamigboye@kwasu.edu.ng; +2348036077451
}

Keywords: Ilado hill, Eruku, Geotourism, Geology, Caves

\begin{abstract}
Geotourism potential of Eruku and its environs with emphasis on Ilado hill was appraised.The methods adopted in this work includes geological field mapping and interview. From the field mapping exercise, the rocks in Eruku and its environs include migmatite, gneisses, amphibolite granites, diorite and pegmatite. The tourist attractions include remnant of ancient city wall (Odi Ilu), joining wall (Odi Abumo) and Ilado hill. Ilado hill was also discovered to be an abandoned ancient city with city gate made of gold with full regalia of African administrative offices. The conclusion drawn from this work is that Ilado hill fulfilled all the requirements to be a tourist destination, and hence, it is a good source of recreation while also serving as source of income for the Eruku City and government at large.
\end{abstract}

\section{Introduction}

Tourist attractions generally range from the naturally occurring structures/features to relatively unique man-made features [1-2]. While examples of the naturally occurring include features such as lake, wild life parks, natural dialect, language among others, the man-made features include ancient constructions such as prison, library, buildings etc [1]. The visit to these features is also aimed at either recreational purposes or educational goal. Recently, tourism is now being seen and considered as a source of income generation to both local people and government at large [3-4]. Geotourism generally describe some geological and/or geographical feature that make a place a relatively tourist destination.

Eruku is a settlement that is located approximately $160 \mathrm{~km}$ east of Ilorin and about $5 \mathrm{~km}$ west of Egbe. The area has attracted a lot of researchers because of among other things, her possible mineralization potential and geology except tourism potential. This work therefore aimed at appraising the tourism potential of Eruku with a focus on Ilado hill. Ilado hill is conically shapeand situated at about $2.5 \mathrm{~km}$ east of Eruku and about $3.5 \mathrm{~km}$ west of Koro (Fig. 1). The hill is relatively step sided and its peak has an elevation of 449 meters above sea level. It is a conspicuous feature that can be seen kilometers from its surrounding and about 600 meters off the road along KoroEruku road.

\section{Materials and Methods}

The methods adopted in this work include field mapping and interview. The field mapping was done between January 13 and 20, 2020. During the field mapping exercise, the geology of the area was appraised and a geological map was produced; Ilado hill was combed to see some of the potential sites for tourist attractions that are associated with it. Necessary field photographs were also taken. Sequels to the success of this exercise, elderly indigenes which include the king, chiefs and a retired educationist in Eruku with vast knowledge of the hill were interrogated. 


\section{Results and Discussion}

\section{Geology of the Study Area}

The geology of Eruku and its environs have been described in details by [5-8]. The rocks that dominate this area were estimated to be of Late Proterozoic to Early Paleozoic age [5]. The rocks are grossly divided into migmatite, gneisses, metabasalt, granite, gabbro, and pegmatite (Fig. 2).

Migmatites occur essentially as pockets of rock within the gneiss. The migmatites are seen in the eastern part of the study area where they occur close to the main road. Also in the southwestern part of the study area, the migmatites are associated with gabbro. The migmatites seen in this area are fine to medium grained and have joints which are oriented in northeastern and northwestern directions essentially. There is no pegmatitic intrusion seen associated with this rock. Xenoliths of gabbro occur as remnants of either unmetamorphosed rocks or undigested pre-existing rock during the magmatic process. The migmatites are composed of 55\% felsic minerals (quartz, Na-feldspar etc.) and 45\% mafic minerals (biotite, muscovite etc.). This composition makes the migmatitic rocks to have intermediate colour i.e. greyish colour. They are generally low-lying outcrops with the largest covering an approximate area of $3.125 \mathrm{~km}^{2}$ in the northeastern part and the smallest of approximate area of $0.94 \mathrm{~km}^{2}$ in the northwestern part of the study area as shown in Fig. 2.The gneisses predominates this area covering approximately $80 \%$ of the total area studied. The gneisses consist essentially of biotite, quartz and sodic feldspar and can be divided into banded grey gneiss, granodiorite gneiss and granite gneiss. The gneisses trend mainly in northeastern direction and have sharp contacts with the granitic rocks that are present in this area. The gneisses like granite have been faulted with the fault planes occupied by pegmatitic intrusion which are differently oriented. Metabasalt occurs at the southwestern part of the study area and as xenolithic bodies and as pockets of rock within the gneisses. It is composed of about $90 \%$ of mafic minerals with some degree of metamorphism.

Granites seen in the mapped area occur essentially in the extreme northeastern part and in the western part of the mapped area. The granite bodies seen are biotite granite, porphyritic granite and fine grained granite and deformed granites. These granites have very sharp contacts with the gneisses and are intruded by pegmatites that trend essentially in north-northeastern direction. They have faults trending essentially northeasternly. These fault zones are filled by pegmatite of different dimensions. The granite bodies are conically shaped in the western part while they form a ridge traceable over $4 \mathrm{~km}$ length in the northeastern part of the area as shown in figure 2. Biotite granite has $35 \%$ biotite, $25 \%$ feldspar, $25 \%$ quartz and $15 \%$ of other minerals while the porphyritic granite is composed of almost equal composition of quartz, feldspar, biotite and other minerals. The feldspar occurs as phenocrysts within the groundmass of other minerals. Like the porphyritic granite, the fine grained granite has almost equal percentage of quartz, feldspar, biotite and other minerals. All these minerals are of almost equal grain size. The deformed granite has been remobilized.

Gabbro seen in the study area occurs as boulders and cobbles arranged in southwestern-northeastern direction and occupy an approximate area of $0.2 \mathrm{~km}^{2}$ in the eastern part of the study area. They have joints trending essentially in east-west and southeast-northwest direction. They are medium grained and composed essentially of mafic minerals. Other occurrences of gabbro were seen at the extreme southwestern part of the study area where it is stream exposed. The gabbro trend in eastwest direction and cover an area of $0.1 \mathrm{~km}^{2}$ (Fig. 2). Other gabbro seen occur as xenolith within the gneisses in the southwestern part of the studied area and migmatitic rocks that are present in this area. Minor rocks seen in the area include pegmatite and quartzite. The pegmatites are hosted essentially by granites and gneisses; and are composed of biotite, quartz, mica, muscovite, feldspar ( $\mathrm{Na}$ and $\mathrm{K}$ ), magnetite and accessory minerals like tourmaline etc. The quartzites are seen in the western part of the area. They are part of zone pegmatites in this area and are closely associated with gabbroic rock in this area. 
Structurally, the area is characterized by brittle, ductile structures. The brittle structures seen in the area include joint (dilated and closed), faults (dextral, sinistral, horst and graben) while the ductile structures include foliation and folds of different geometry. The foliations seen include first folia and second folia that are well developed on the road cut exposure besides First ECWA (Fig. 3).

\section{Historical Background}

According to Fadipe (Int. Personal Communication, 2020), Ilado is the name of a settlement around the hill. This community existed before the period of Atlantic Slave Trade in $16^{\text {th }}$ to $19^{\text {th }}$ centuries and was characterized with the full complement of African administrative executives that range from King to Chiefs and family heads. The king has the final pronouncement on any matter and also doubled as the chief counselor for the community in some critical situations. Ilado community has her market situated on the hill and at the foot of the hill and as a means of security; Ilado has a city gate made of gold.

The existence of this community was threatened during the slave trade period as a result of slave rustlers' invasion. Ilado as a community continued to shrink in population as a result of slave rustlers' invasion until the reigning king, then, thought and advised the youth and other willing member of the community to relocate to Eruku, a nearby community that is situated on the plain with an admonition that his subjects that are willing to go to Eruku should not vie or aspire to be install as king in Eruku. It is however noteworthy that as one of the preventive measures against the invasion of slave rustlers/traders; Eruku has started construction of a city wall called 'Odi- Ilu' before the arrival of the people of Ilado. The city wall was however too demanding for the people of Eruku as at that time to complete, hence, the construction of a smaller wall to secure areas that were occupied by the inhabitant at that time alone. This smaller wall was described as 'Odi-Abumo' meaning the joining wall. These walls form the basis for description of Eruku as a city in contrast to ideal description of town or village and the remnant of these walls are still preserved in Eruku till date.

The remnant of Ilado community later died, captured as slave or relocated to nearby communities as a means of survival thereby leading to an end of Ilado as a Community. The city gate of Ilado was however buried in an unknown location between Eruku and Koro when the left-over of Ilado people finally move out of the hill. It is however important to note that natives of the ancient Ilado town are still are still a people group in Eruku till today. They currently reside in Ilado compound and still oversee their lands up to Koro, east of Eruku.

\section{Tourism Potential of Ilado Hill}

Ilado hill play host to 3 large caves (Fig. 4a) and about 5 smaller caves (Fig 4b). These caves are at the limbs and crest of the hill. Each of the large caves, depending on the sitting arrangement, can accommodate between 20 and 40 people at a time (Fig. 5). They are generally characterized by at least two entrances while one is with three entrances. In addition, these caves provide shelter for the ancient people of Ilado and serve as a place of refuge during the period of African civil war and to some extent, the era of slave trade. It is however sadden that these caves are now inhabited by wild animals especially during the raining season. The smaller caves were not assessed because of their narrowness and fear of dangerous reptiles that may now inhabit the caves. In addition, the plane on the crest (Fig. 6) is suitable for retreat and picnic and can accommodate more than 100 people at a time.

Secondly, record has it that Ilado hill played host to some traditionalist before the advent of Christianity and Islam in Eruku. The Chief Priest, during their festival usually leads his followers to Ilado hill where he will climb up to the crest of the hill to display his dancing skill. His followers usually leave him behind on the hill crest and trek back to Eruku. This Chief priest will still be seen dancing on the hill top until few meters to their house where he will be seen in the house seated on a chair and welcoming his followers. This display of traditional power from Ilado Hill to Eruku town was an annual ritual until the firm grip of Christianity and Islam on the town. 


\section{Qualitative Site Evaluation}

After a geological site has been investigated and identified, [9] noted that qualitative evaluation for tourism potential should be carried out. This evaluation is suggested to be made based on the parameters which include the scenery, interpretive potential, accessibility, and safety. The Scenery is related to the beauty of the proposed site elements. Interpretive potential is concerned with the ability of the site to be easily understood by visitors. Accessibility as one of the criteria in geotourism site investigation relates to the means and conditions considering the difficulties and time through which the site can be reached. Safety in geotourism site investigation has to do with the conditions of visit to the site, considering the least risk posed to the people while around the site. It is interesting to note that the Ilado hill met all these criteria needing only very slight improvement to bring the geological elements in the area to the status of an interesting geotourism site.

\section{Conclusions}

This study revealed that the Ilado hill and it environs possess geological elements with geotourism potential. According to the results of geological field investigation, the identified geological elements in this area present a great geological and geomorphological wealth which, if not developed and promoted, will continue to lie fallow. It is important to note that the Ilado hill favorably meets all the geotourism site investigation criteria which include scenery, interpretive potential, accessibility, and safety needing very slight improvement to upgrade the status of the area to an interesting geotourism site.

\section{Conflict of Interest}

The authors hereby declared that they have no conflict of interest.

\section{Acknowledgement}

The authors appreciate the cooperation and encouragement given by His Royal Majesty, Oba Olanrewaju Busari, The Owa of Eruku during the course of this work. 


\section{Figures}

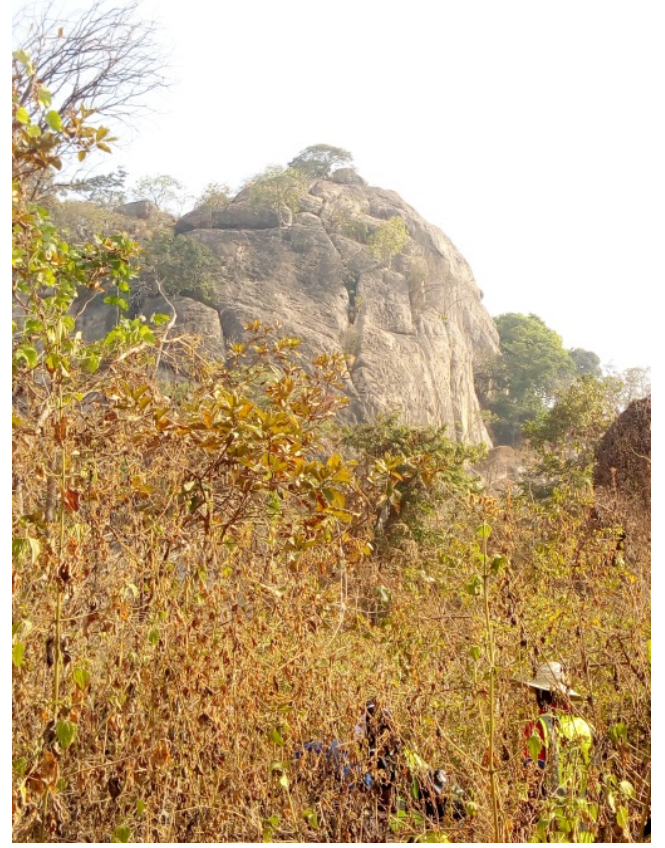

Fig. 1: Field photograph showing panoramic view of Ilado hill

$5^{\circ} 22^{\prime} 45^{\prime \prime} \mathrm{E}$

$5^{\circ} 30^{\prime} \mathrm{E}$
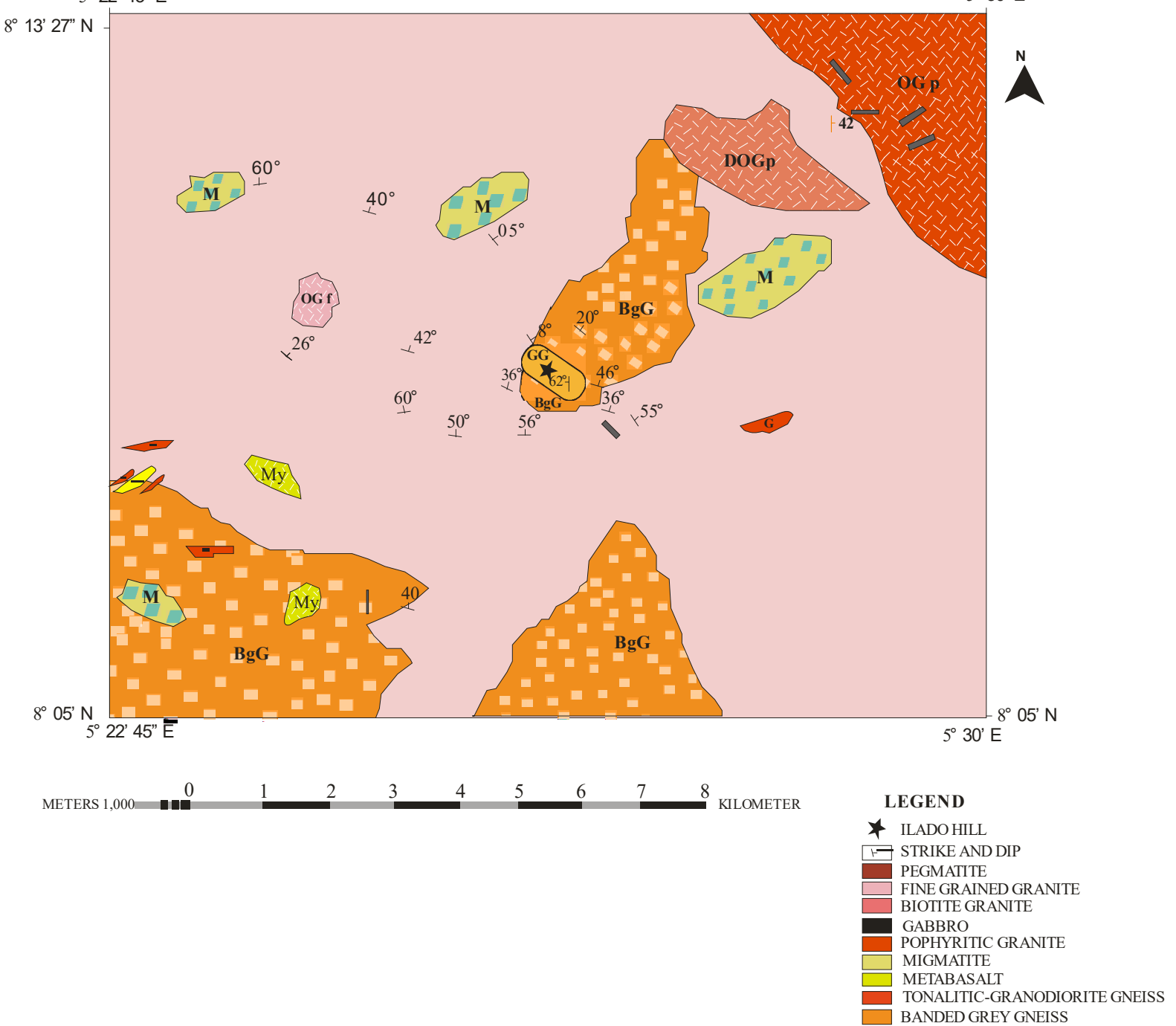

Fig. 2: Geological Map of Eruku and its Environs 


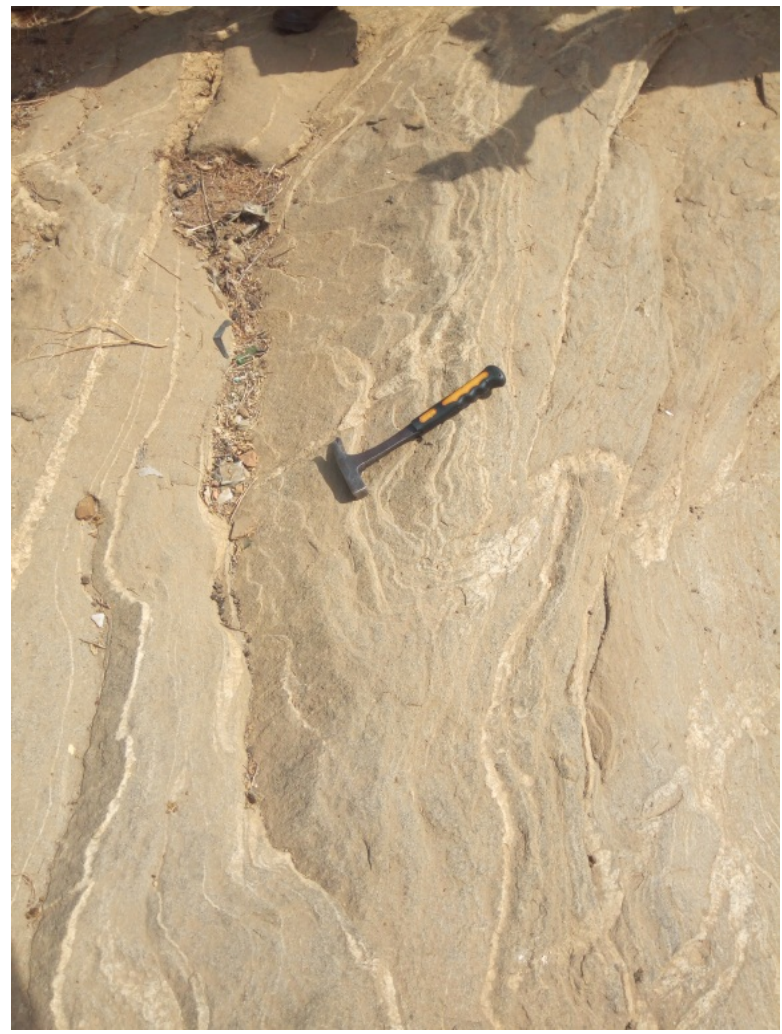

Fig. 3: Field photograph showing the foliations in migmatite of Eruku

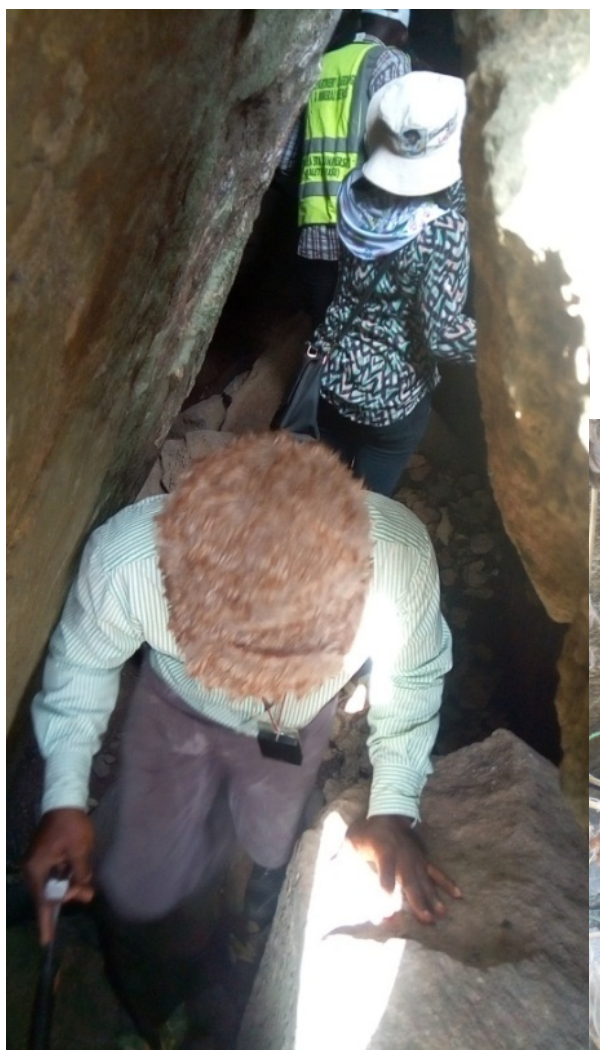

a

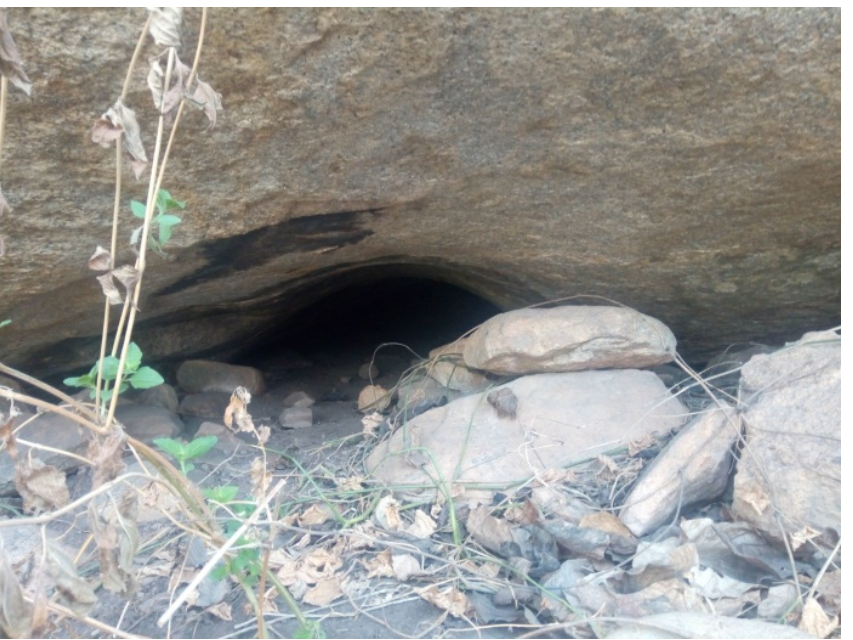

$\mathrm{b}$

Fig. 4: Field photograph showing entrance to the larger (a) and smaller (b) caves 


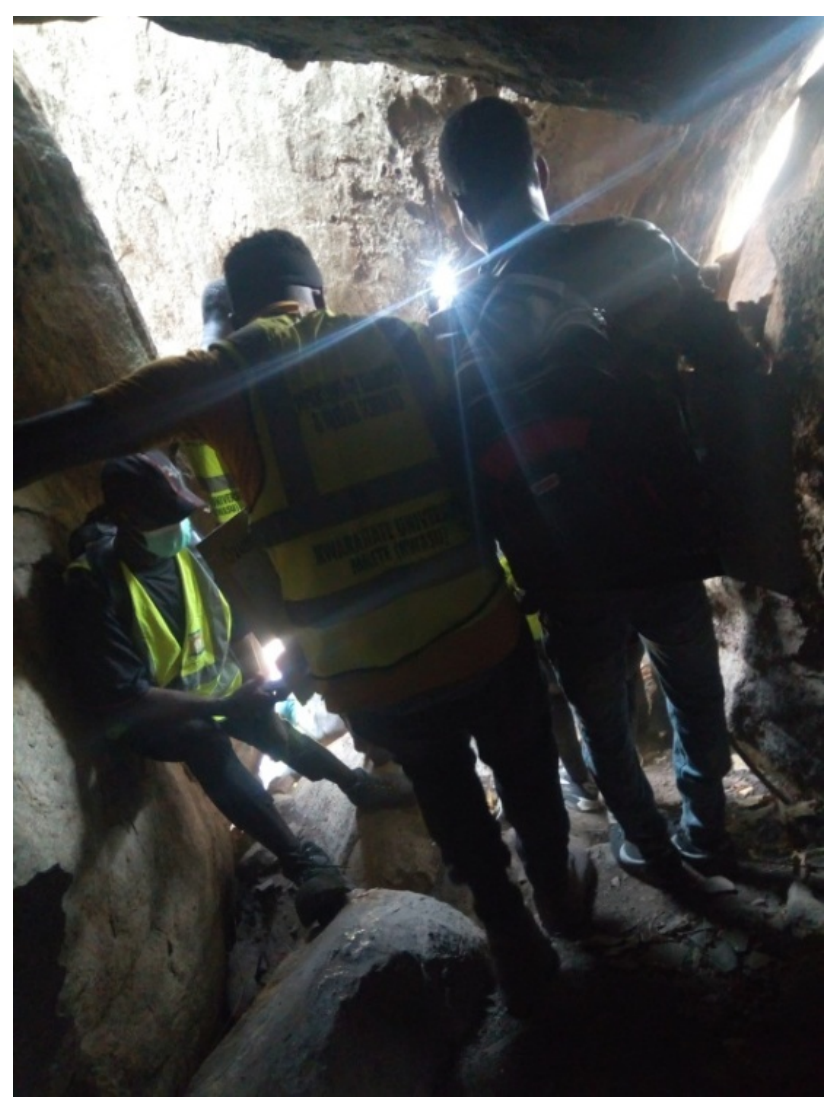

Fig. 5: Field photograph showing some students in one of the caves during field work

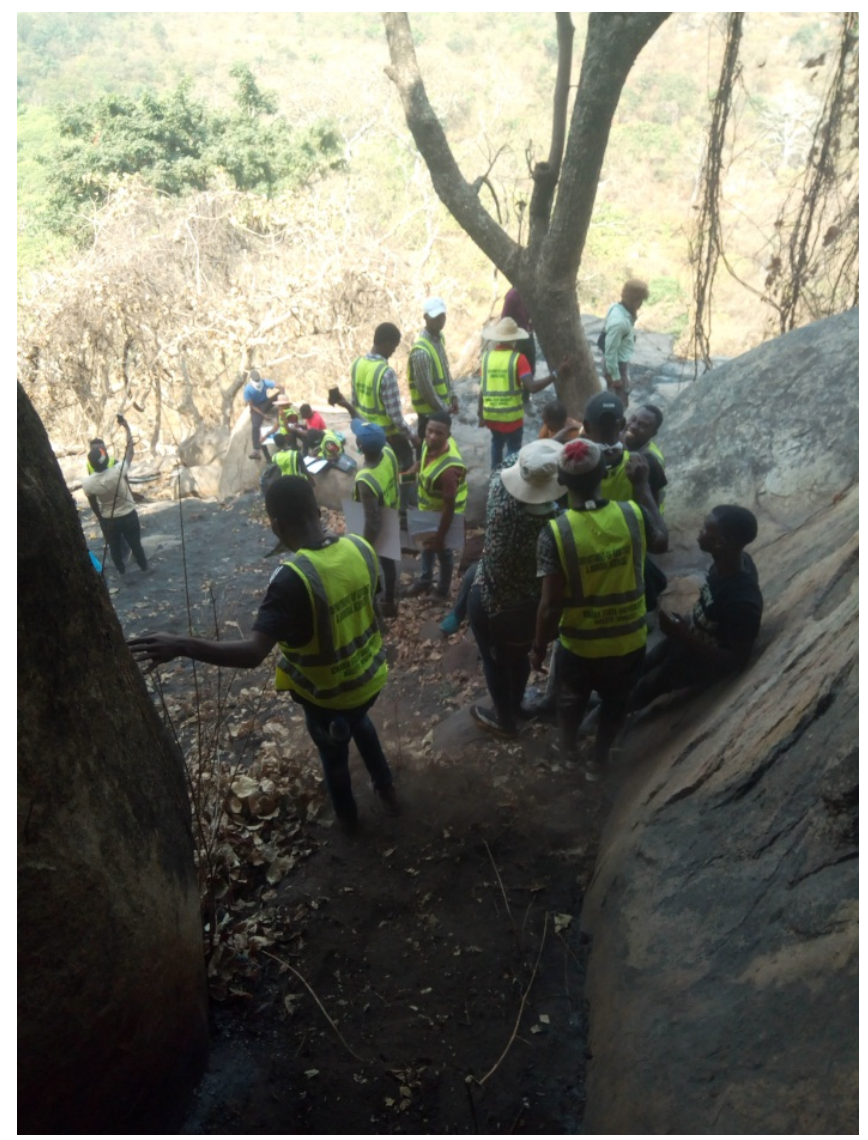

Fig. 6: Field photograph of students on the plane at the crest of Ilado hill during field work 


\section{References}

[1] D., Chylińska, and K., Kołodziejczyk, (2018).Geotourism in an urban space?. Open Geosci., 10: 297-310.

[2] N. G., Goki, S., Iyakwari, and A. A., Umbugadi, (2018). Geotourism and Mining Heritage: a Potential Gold Mine for Central Nigeria. Acta Geoturistica, 9 (1): 9-22

[3] A., George (2014). Assessing the Niche Tourism Products of Lokoja Township, International Journal of Public Administration and Management Research (IJPAMR), 2(3):98-103.

[4] E. M., Audu-Vincent, K., Bitrus, I. I., Lawan, and U. Jibrin (2018).An Overview of Geotourism Potentials in Managing the Menace of Insecurity within Mubi Region and Environs, North Eastern Nigeria. International Journal of Engineering Research and Technology (IJERT), 7(7): 23 - 24.

[5] J.I.D., Adekeye and A.D., Adedoyin (2007) Economic Potentials of the Pegmatites of Eruku Area,South-Western Nigeria. Continental Journal of Earth Sciences, 1 (2): 1-6.

[6] O. S., Bamigboye, and J. I. D., Adekeye (2011). Stream Sediments Survey of Eruku and its Environs, Central Nigeria: Implication for Exploration. International J. of Research and Reviews in Applied Sciences, 7(2): 160 - 171.

[7] O. A., Omorinoye and J.I.D., Adekeye (2013). Geochemical Studies of Soils of Eruku and its environs. Jnl of Environment and Earth Sciences, 3(7), 105 - 115.

[8] A. D., Adedoyin, O. S., Bamigboye, J.I.D. Adekeye, and Ojo, O. J. (2013).Ductile Shearing and Remobilization of Porphyritic Granite in Koro- Egbe Area, Southwestern Nigeria. Science focus, 18(1):73-77.

[9] J., Brilha (2015). Inventory and Quantitative Assessment of Geosites and Geodiversity Sites: a Review. Geoheritage, 8:119-134. 